\title{
Variation in 'Bayou Belle' and 'Beauregard' Sweetpotato Root Length in Response to Experimental Phosphorus Deficiency and Compacted Layer Treatments
}

\author{
Arthur Villordon ${ }^{1}$ and Jeffrey Cole Gregorie \\ LSU AgCenter Sweet Potato Research Station, Chase, LA 71324
}

\author{
Don LaBonte \\ LSU AgCenter School of Plant, Environmental, and Soil Sciences, 137 J.C. \\ Miller Hall, Baton Rouge, LA 70803-2120
}

\begin{abstract}
Awais Khan
Plant Pathology and Plant-Microbe Biology Section, Cornell University, Geneva, NY 14456 [formerly with the International Potato Center (CIP), Lima 12, Peru]
\end{abstract}

\section{Michael Selvaraj International Center for Tropical Agriculture (CIAT), Cali, Colombia}

Additional index words. Ipomoea batatas, storage root development, length/width ratio

\begin{abstract}
Phosphorus deprivation ( $-\mathrm{P}$ ) reduced sweetpotato storage root length (SRL) regardless of the presence or absence of a compacted layer $(C L)$. The combination of $-P$ and the presence of a simulated compacted layer $(+C L)$ reduced SRL relative to the $P$-sufficient $(+P)$ control plants grown without a compacted layer $(-C L)$ by $44 \%$ and $40 \%$, respectively, in 'Bayou Belle' and 'Beauregard' cultivars. In both cultivars, the combination of $-P$ and $-C L$ also reduced SRL by $36 \%$ ('Bayou Belle') and $28 \%$ ('Beauregard') relative to the control plants. There was a significant planting date $\times$ cultivar effect in the temporal $-P$ studies, with a general trend for SRL reduction with $-P$ at 10-day intervals over a 50-day growing period. - $P$ treatment reduced 'Bayou Belle' SRL after 10 days but not after 20 days. In $P$ source plant status studies, the $-P /-P$ treatment (source plant $P$ status/daughter plant $P$ status) was associated with $50 \%$ and $48 \%$ reduction in $S R L$ in 'Bayou Belle' and 'Beauregard' daughter plants, respectively, relative to the $+\mathrm{P} /+\mathrm{P}$ control plants. Taken together, these findings corroborate previous experimental evidence on the role of $P$ in determining root length in other plant species and experimental systems. These experimental findings have practical applications in the management of $P$ in sweetpotato seed and production systems. The results of the current study can lead to follow-up work that validates cultivar-specific $P$ requirements and how such information can be used to optimize $P$ management as it relates to the production of storage roots of consistent length and shape. The methods and approaches used in the current study can be adopted and modified in follow-up investigations that seek to shed light on the precise mechanisms of SRL determination in sweetpotato.
\end{abstract}

Received for publication 18 June 2018. Accepted for publication 3 Aug. 2018.

Portions of this research were supported by the CGIAR Research Program on Roots, Tubers and Bananas (RTB) - U.S. Universities Linkage Fund 2016 and the Louisiana Sweet Potato Advertising and Development Fund.

Approved for publication by the Director of the Louisiana Agricultural Experiment Station as manuscript number 2018-260-32227. Mention of trademark, proprietary product or method, and vendor does not imply endorsement by the Louisiana State University Agricultural Center nor its approval to the exclusion of other suitable products or vendors. ${ }^{1}$ Corresponding author. E-mail: avillordon@agcenter. lsu.edu.

This is an open access article distributed under the CC BY-NC-ND license (http://creativecommons. org/licenses/by-nc-nd/4.0/). essing industry, especially in French fry processing, uniform, round-shaped storage roots are desirable to reduce nonuniform slices (Hoque and Saha, 2017). Consistency in SRL also is desirable for increased mechanization, leading to overall reduced cost of production (Tang et al., 2017). Based on experimental findings in plant model systems, there is growing evidence that points to the root tip as the site of $\mathrm{P}$ sensing and that $\mathrm{P}$ is involved in root length determination (Abel, 2017; Kellermeier et al., 2014; Medici et al., 2015; Svistoonoff et al., 2007). There is also substantial evidence that supports the role of soil compaction or mechanical impedance on root growth in plant species (Lipiec et al., 2012; Oussible et al., 1992; Taylor and Brar 1991). Despite the available evidence, very little translational research has been conducted to determine the role of $P$ and soil compaction in SRL determination in sweetpotato and other root crops.

Past research on the role of $\mathrm{P}$ in sweetpotato focused mostly on storage root yields (Bouwkamp, 1985) and some quality factors like starch quality (Noda et al., 1996) but not SRL. More importantly, these studies determined that storage root yield responses were not consistently observed when soil $\mathrm{P}$ was greater than $52 \mathrm{ppm}$ (Bouwkamp, 1985). This underscores the challenges of studying specific responses to $\mathrm{P}$ treatments under field conditions where external $\mathrm{P}$ availability can confound the treatment effects. Moreover, in sweetpotato production systems, vegetative cuttings or slips are obtained from extant source plants or sprouted roots. Hence, a practical question is whether the $\mathrm{P}$ status of the source plant affects the subsequent performance of plants subjected to experimental treatments. There is precedent for this possibility because it has been previously documented that certain plant species, if deprived of external phosphate supply, will grow for a period of weeks using internal $\mathrm{P}$ stores (Nassery, 1970). Knowledge of this information can be used to improve the accuracy of studying the relationship of $\mathrm{P}$ availability and storage root yield response in sweetpotato. The main objective of this work was to translate findings from model systems by testing the hypothesis that $-\mathrm{P}$ and soil compaction are associated with sweetpotato SRL determination. A secondary goal of this work was to contribute to the development of standardized procedures and methods that can be used to further study the role of $\mathrm{P}$ in storage root development in controlled experimental conditions.

Experiments were conducted to assess the effects of $\mathrm{P}$ deficiency and soil compaction

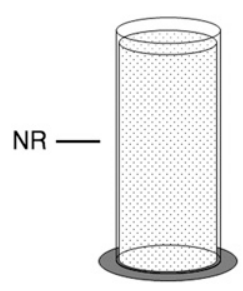

A

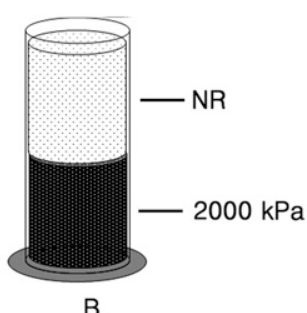

B
Fig. 1. Materials and methods used to simulate a compacted layer in greenhouse experiments. The growth substrate was poured into the container with minimal disturbance (A) to simulate the lack of a compacted layer. A 15 $\mathrm{cm}$ compacted layer $(\mathbf{B})$ was created by shaking the container as the growth substrate was gradually poured while simultaneously adding water. The mixture was allowed to sit overnight to harden. Subsequently, additional substrate was added without disturbance to the top $15 \mathrm{~cm}$ of the container. Resistance was measured at $2000 \mathrm{kPa} . \mathrm{NR}=$ no resistance recorded. 
on SRL in sweetpotato cvs. Bayou Belle and Beauregard. 'Bayou Belle' (formerly designated as breeding line $07-146$ ), is an orange-

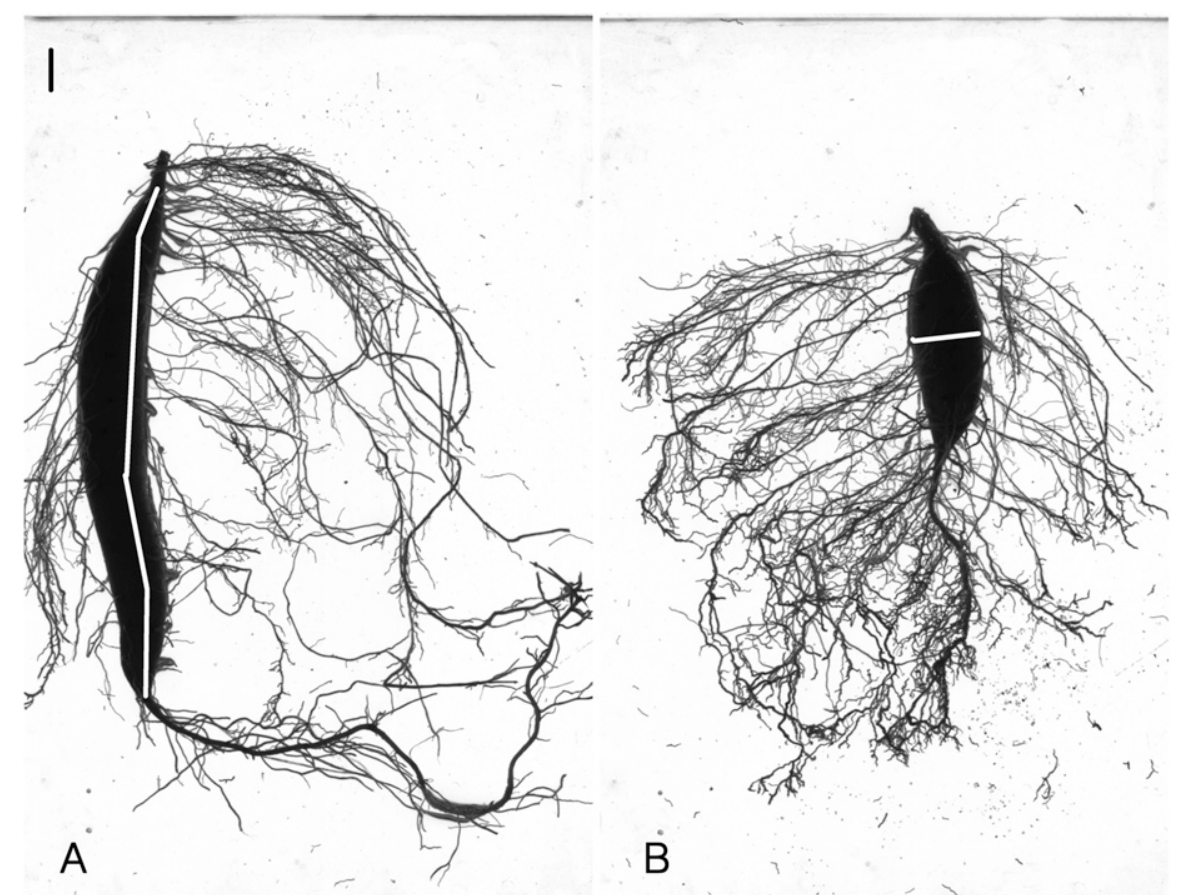

Fig. 2. Illustration depicting the digital measurements of sweetpotato storage root length (A) and diameter (B) using the segmented line and straight-line features, respectively, of ImageJ. Scale bar $=1 \mathrm{~cm}$. fleshed variety released specifically for the processing market. This cultivar has shown $3 \%$ to $47 \%$ increase in total marketable yield

relative to 'Beauregard', depending on location and year (LaBonte et al., 2013). 'Beauregard', also an orange-fleshed variety, was released in 1987 (Rolston et al., 1987) and continues to be grown commercially on a global scale.

\section{Materials and Methods}

Plant materials and experimental conditions. The greenhouse experiments were carried out from 3 May 2016 to 1 Mar. 2018 in Chase, LA $\left(32^{\circ} 6^{\prime} \mathrm{N}, 91^{\circ} 42^{\prime} \mathrm{W}\right)$. In Feb., May, and Sept. in each of 2016, 2017, and 2018 (Feb. only), virus-tested 'Bayou Belle' and 'Beauregard' Generation 1 Storage roots were bedded in plastic containers containing soilless media (Sungro; Sun Gro Horticulture, Bellevue, WA) and served as a source of transplants for subsequent experiments. In each experiment, cuttings were set in $10-\mathrm{cm}$ diameter polyvinyl chloride pots (height $=30 \mathrm{~cm}$ ) with detachable plastic bottoms. Each plastic bottom had five drain holes (2 $\mathrm{mm}$ in diameter). In addition, each polyvinyl chloride pot had four rows of side drain holes $(2 \mathrm{~mm}$ in diameter; $3 \mathrm{~cm}$ apart within row) that were located diametrically opposite each other. These side drain holes were added to help reduce the incidence of a perched water table (Bilderback and Fonteno, 1987). Washed river sand was used as growth substrate for all experiments. The diameter of the sand particles varied from

A

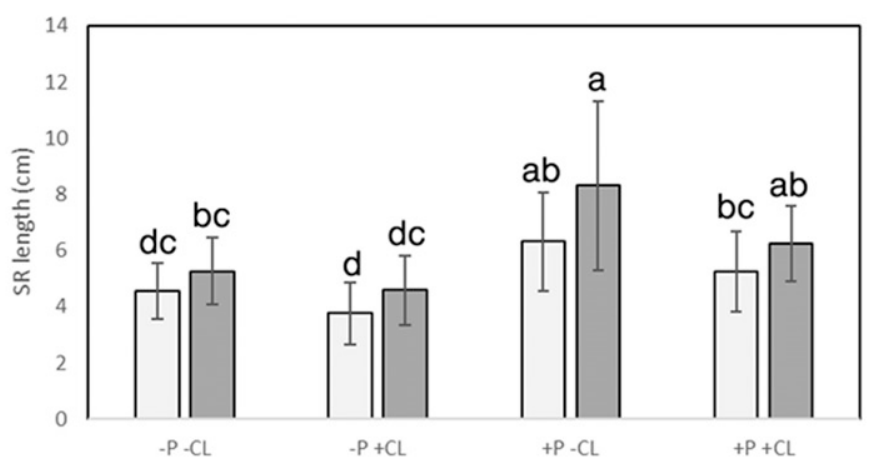

C

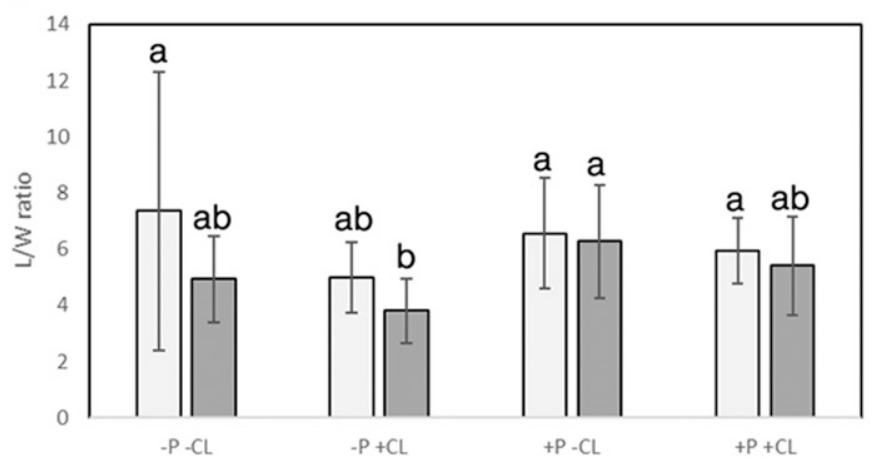

B

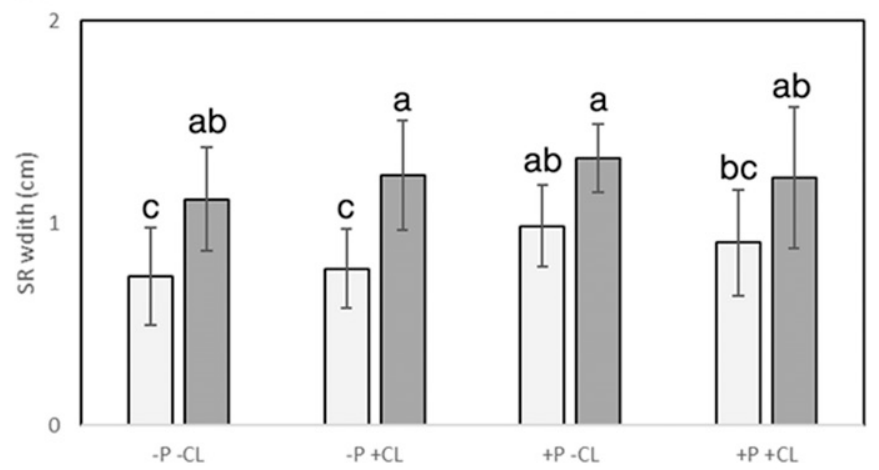

D $\square B \times \square B B$

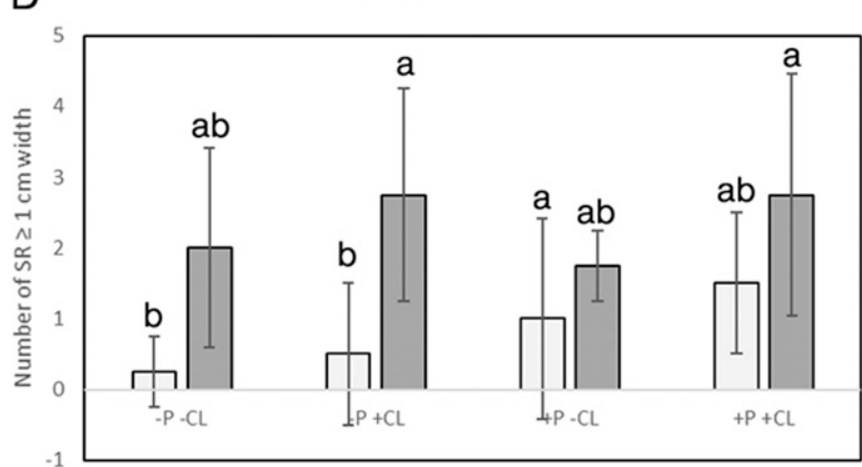

Fig. 3. SR length (A), SR width (B), L/W ratio (C), and number of SR (D) in 'Bayou Belle' and 'Beauregard' sweetpotato subjected to phosphorus deficiency and compaction treatments. Mean comparisons were performed on transformed data: $\log 10$ transformed (quantitative data), square root transformed (counts), and arcsine transformed (ratios). Corresponding nontransformed mean values with SD are shown. Columns with different letters differ significantly at the $5 \%$ level by Fisher's least significant difference. $\mathrm{BX}=$ 'Beauregard'; $\mathrm{BB}=$ 'Bayou Belle'; $\mathrm{SR}=$ storage root; $-\mathrm{P}=$ no phosphorus; $-\mathrm{CL}=$ no compacted layer; $+\mathrm{CL}=$ with compacted layer; $+\mathrm{P}=$ with phosphorus; $\mathrm{L} / \mathrm{W}$ ratio $=$ length/width ratio. 
0.05 to $0.9 \mathrm{~mm}$, with the majority $(83 \%)$ in the 0.2 - to $0.9-\mathrm{mm}$ range. In all experiments, vegetative terminal cuttings were selected that were 25 to $30 \mathrm{~cm}$ long, with five to six fully opened leaves, $\approx 5 \mathrm{~mm}$ diameter at the basal cut, and with uniform distribution of nodes. Cuttings were planted to a uniform depth of $8 \mathrm{~cm}$ with two to three nodes under the growth substrate surface, depending on cultivar. In general, 'Bayou Belle' had 50\% more nodes per unit length of cutting relative to 'Beauregard'. All experiments were arranged as a randomized complete block repeated across planting dates. Unless otherwise indicated, there were four replicates in each experiment (one plant per pot equals one replicate). Plants were grown for $50 \mathrm{~d}$, after which near-intact root systems were collected. At harvest, the detachable plastic bottoms were removed, and the pot was tilted to gradually remove the growth medium and near-intact root system. These experimental approaches have been used to validate storage root initiation timing in 'Beauregard' (Villordon et al., 2009a, 2009b, 2012), characterize nitrogen and moisture availability on 'Beauregard' root architecture (Villordon et al., 2012, 2013), quantify drought effects on gene expression and storage root width and weight in 'Beauregard' (Solis et al., 2014), and document the simultaneous effects of virus infection and nitrogen availability on storage root initiation in 'Beauregard' (Villordon and Clark, 2014).

Growth substrate moisture was measured with $\mathrm{ECH} 2 \mathrm{O}$ soil moisture sensors (Model
EC-5; Decagon Devices Inc., Pullman, WA) inserted vertically at the $2-7 \mathrm{~cm}$ depth. The moisture of the growing medium ranged from $5 \%$ to $9 \%$ volumetric water content (VWC), where $\approx 50 \%$ of field capacity $=7 \%$ VWC. At saturation, the growing medium typically ranges from $12 \%$ to $14 \%$ VWC (Villordon et al., 2012). The greenhouse temperature regime was $29^{\circ} \mathrm{C}$ (SD 6.3) for $14 \mathrm{~h}$ (day) and $23{ }^{\circ} \mathrm{C}$ (sD 3.3) for $10 \mathrm{~h}$ (night). The relative humidity (RH), measured hourly, averaged $60 \%$ (SD 15.6). The temperature and RH were monitored at the canopy level using an integrated temperature and RH sensor (Model RHT; Decagon Devices Inc.). Supplementary lighting was provided using LED grow lights (LumiBar; Lumigrow Inc., Emeryville, CA) for $14 \mathrm{~h}$ per day. Photosynthetic photon flux $(P P F)$ ranged from 300 to $1400 \mu \mathrm{mol} \cdot \mathrm{m}^{-2} \cdot \mathrm{s}^{-1}$. $P P F$ was measured at the canopy level with a quantum sensor (Model QSO-S; Decagon Devices Inc.). These growth conditions were very similar to those used in previous experiments that characterized adventitious root development and the timing of storage root initiation in 'Beauregard' sweetpotato (Villordon et al., 2009a, 2009b, 2012).

Description of studies. The $\mathrm{P}$ deprivation and compaction study (PCOMP) simulated -P simultaneously with the presence of a CL in 'Bayou Belle' and 'Beauregard'. Replicate experiments were conducted on 8 Apr. 2016 and 4 July 2017. The control nutrient treatment $(+\mathrm{P})$ consisted of half-strength Hoagland nutrient solution $(\mathrm{P}=15.5 \mathrm{ppm})$ with nitrogen supplied as nitrate only (Solution 1), whereas $\mathrm{KH}_{2} \mathrm{PO}_{4}$ was omitted in the $-\mathrm{P}$ treatment (Hoagland and Arnon, 1950). The final concentration of $\mathrm{K}^{+}$ions was similar in both $-\mathrm{P}$ and $+\mathrm{P}$ treatments, and $\mathrm{pH}$ was maintained at 6.0 for the duration of the experiments. In total, $150 \mathrm{~mL}$ of control and -P treatments was applied to pots every other day starting at planting. The concentration, amount, and interval of $+\mathrm{P}$ and -P treatments were similar for all subsequent studies. The compaction treatment was simulated by compacting the growth substrate in the bottom half $(15 \mathrm{~cm})$ of the pot by shaking and gradually adding water (Fig. 1). The mixture was allowed to sit overnight to harden. A cone penetrometer (DICKEY-John Corp., Auburn, IL) was used to measure resistance of the CL to $2000 \mathrm{kPa}$, which is commonly considered to be root-restricting (Bengough and Mullins, 1990; Loboski et al., 1998; Materechera et al., 1991). Subsequently, growth substrate was added to fill the pot to $2 \mathrm{~cm}$ below the rim of the pot. The non-CL did not register any resistance to the cone penetrometer measurements. Pots filled up to $2 \mathrm{~cm}$ below the rim with noncompacted growth substrate were used in all other studies.

The $\mathrm{P}$ deprivation timing study (PTIME) simulated the temporal deprivation of $\mathrm{P}$ in the growth substrate. This study tested the hypothesis that the temporal availability of $\mathrm{P}$ in the growth medium played a role in determining SRL. Replicate experiments were conducted on 14 Aug. 2016 and 9 Oct. 2016. There were
A

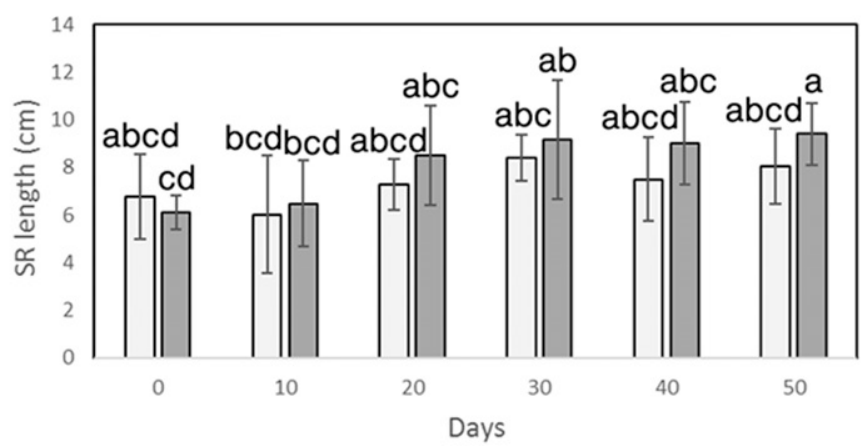

C

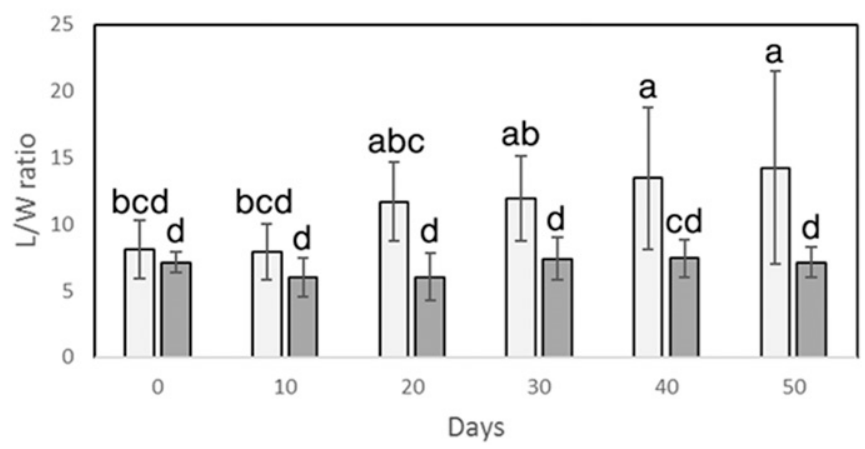

B

$\square B X \square B B$
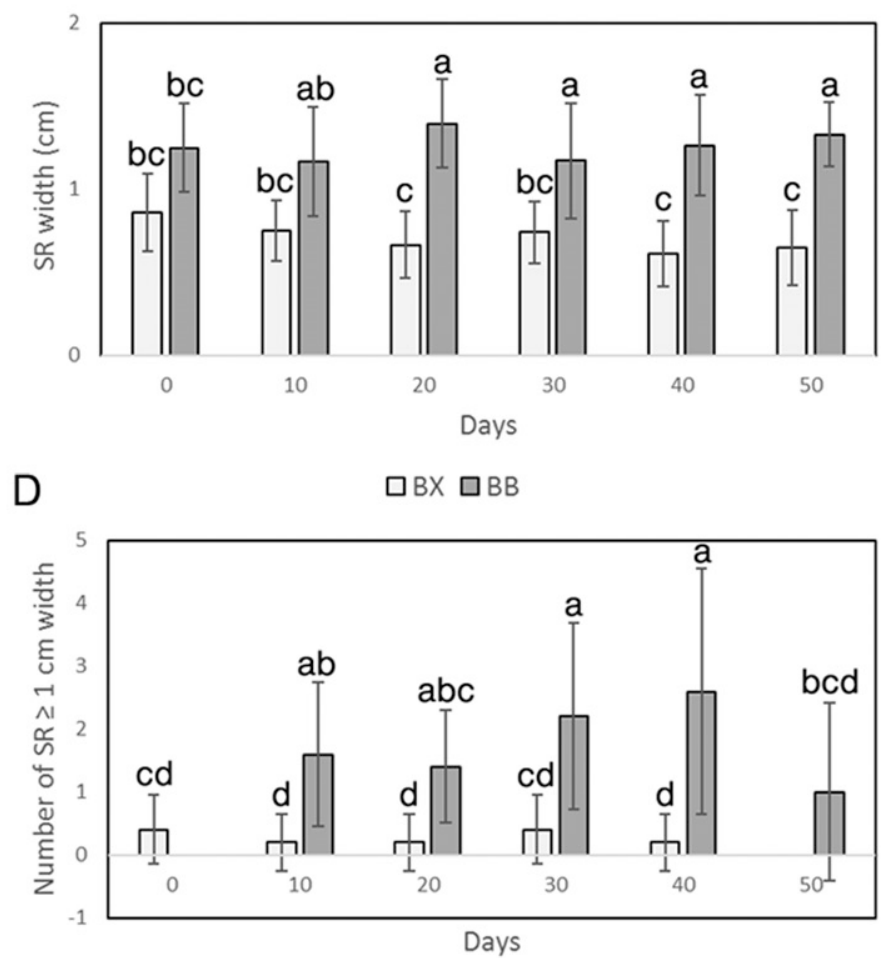

Fig. 4. SR length (A), SR width (B), L/W ratio (C), and number of SR (D) in 'Bayou Belle' and 'Beauregard' sweetpotato subjected to temporal phosphorus deprivation treatments (Study 1). Mean comparisons were performed on transformed data: log 10 transformed (quantitative data), square root transformed (counts), and arcsine transformed (ratios). Corresponding nontransformed mean values with sD are shown. Columns with different letters differ significantly at the $5 \%$ level by Fisher's least significant difference. $\mathrm{BX}=$ 'Beauregard'; $\mathrm{BB}=$ 'Bayou Belle'; SR = storage root; $0=$ plants did not receive P; $50=$ plants received $\mathrm{P}$ throughout the duration of the study; $10,20,30,40=\mathrm{P}$ was withheld after $10,20,30$, and $40 \mathrm{~d}$; $\mathrm{L} / \mathrm{W}$ ratio $=1$ length/width ratio. 
six experimental treatments: $\mathrm{P}$ sufficiency control ( $\mathrm{P}$ applied for $50 \mathrm{~d}$ ), $-\mathrm{P}$ control, and withholding of $P$ after 10, 20, 30, and $40 \mathrm{~d}$. The plants were grown for $50 \mathrm{~d}$.

The P deprivation status study (PSTATUS) tested the hypothesis that source plant $\mathrm{P}$ status influenced the performance of daughter plants. $\mathrm{P}$ deficiency was simulated in plant materials by growing 'Bayou Belle' and 'Beauregard' source plants in $+\mathrm{P}$ control and $-\mathrm{P}$ conditions and obtaining cuttings at $25 \mathrm{~d}$. After $25 \mathrm{~d}$, older leaves in -P source plants gradually senesced, consistent with $\mathrm{P}$ deficiency symptoms in the crop (O'Sullivan et al., 1993). The cuttings (daughter plants) were subsequently planted in control and $-\mathrm{P}$ conditions and grown for $50 \mathrm{~d}$. The final experimental treatments for the source plant/daughter plant combinations were control/control $(+\mathrm{P} /+\mathrm{P})$, control/-P $(+\mathrm{P} /-\mathrm{P})$, $-\mathrm{P} /$ control $(-\mathrm{P} /+\mathrm{P})$, and $-\mathrm{P} /-\mathrm{P}$. Replicate experiments were conducted on 13 Aug. 2017 and 27 Jan. 2018. On 12 Jan. 2017 and Nov. 15 2017, separate 'Bayou Belle' and 'Beauregard' plants were grown under control and $-\mathrm{P}$ conditions for source plant $\mathrm{P}$ leaf tissue $\mathrm{P}$ analysis. Leaf tissue samples were (fifth fully opened leaf) (Mortley and Hill, 1990) collected $25 \mathrm{~d}$ after planting and sent to Waypoint Analytical (Memphis, TN) for leaf tissue nutrient analysis.

Root image acquisition and analysis. In all experiments, storage root samples were photographed and images were digitally an- alyzed using ImageJ (Schneider et al., 2012). The segmented line feature was used to measure SRL whereas the straight-line feature was used to measure storage root diameter (Fig. 2). Length/width ratio (L/W ratio) was subsequently calculated (Villordon and Carroll, 2002; Villordon et al., 2013). L/W ratio has been used to describe shape in agricultural products (Costa et al., 2011), where if an object has $\mathrm{L} / \mathrm{W}$ ratio $=1$, then it is circular (Kaiser et al., 2006).

Data collection and statistical analysis. All quantitative and count data were transformed using $\log 10$ and square root transformation, respectively. Ratios were arc sine transformed. Statistical analyses were performed on transformed values with significant differences inferred at $P<0.05$. The data sets were analyzed using SAS Proc Mixed (SAS v. 9.1; SAS Inc., Cary, NC). There were no interactions $(P \geq 0.05)$ among the main effects and planting date in PCOMP and PSTATUS studies; hence, the data were combined for each study. There was a significant planting date $\times$ cultivar interaction in the PTIME study; hence, the data were presented according to the planting date.

\section{Results and Discussion}

$-P$ and compaction. -P exerted significant effect on SRL in 'Bayou Belle' and
'Beauregard', regardless of the presence or absence of a CL (Fig. 3A). Storage root width, $\mathrm{L} / \mathrm{W}$ ratio, and count also varied, depending on cultivar (Fig. 3B-D). The combination of $-\mathrm{P}-\mathrm{P}+\mathrm{CL}$ reduced $\mathrm{SRL}$ by $44 \%$ and $40 \%$, respectively, in 'Bayou Belle' and 'Beauregard'. The $-\mathrm{P}-\mathrm{CL}$ treatment reduced SRL by $36 \%$ and $28 \%$, respectively, in 'Bayou Belle' and 'Beauregard'. 'Bayou Belle' showed generally greater number of storage roots $\geq 1$ $\mathrm{cm}$ width relative to 'Beauregard' (Fig. 3D). This is likely due in part to the presence of more nodes per unit length of cutting in 'Bayou Belle' relative to 'Beauregard'. The cultivar-specific variation in storage root count is consistent with the yield potential for each cultivar (LaBonte et al., 2013). In general, the results appear to show a trend toward a reduction in SRL due to CL in Psufficient conditions but inherent variability in the root samples, as evidenced by the SD, likely contributed to the nonsignificant results. Wolfe et al. (1995) documented the contrasting results between field and greenhouse soil compaction studies among four vegetable species and attributed the inconsistent results to species-specific responses to secondary effects like soil water status, leaf turgor, nutrient deficiency, and net $\mathrm{CO}_{2}$ assimilation of individual leaves. This underscores some of the technical challenges of conducting soil compaction studies in both greenhouse and field conditions and highlights
A

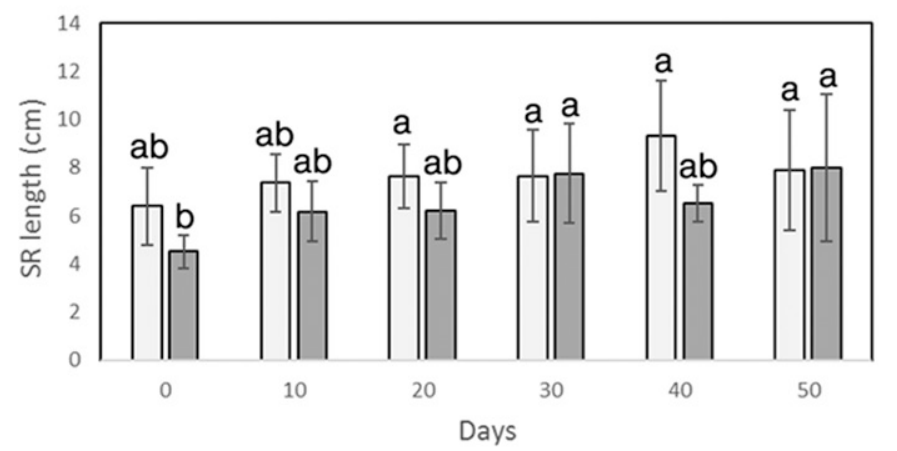

C

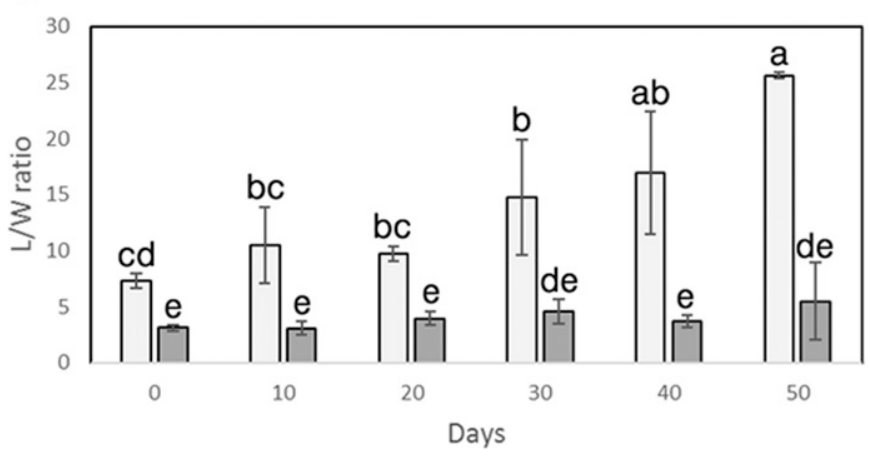

B $\square B X \square B B$
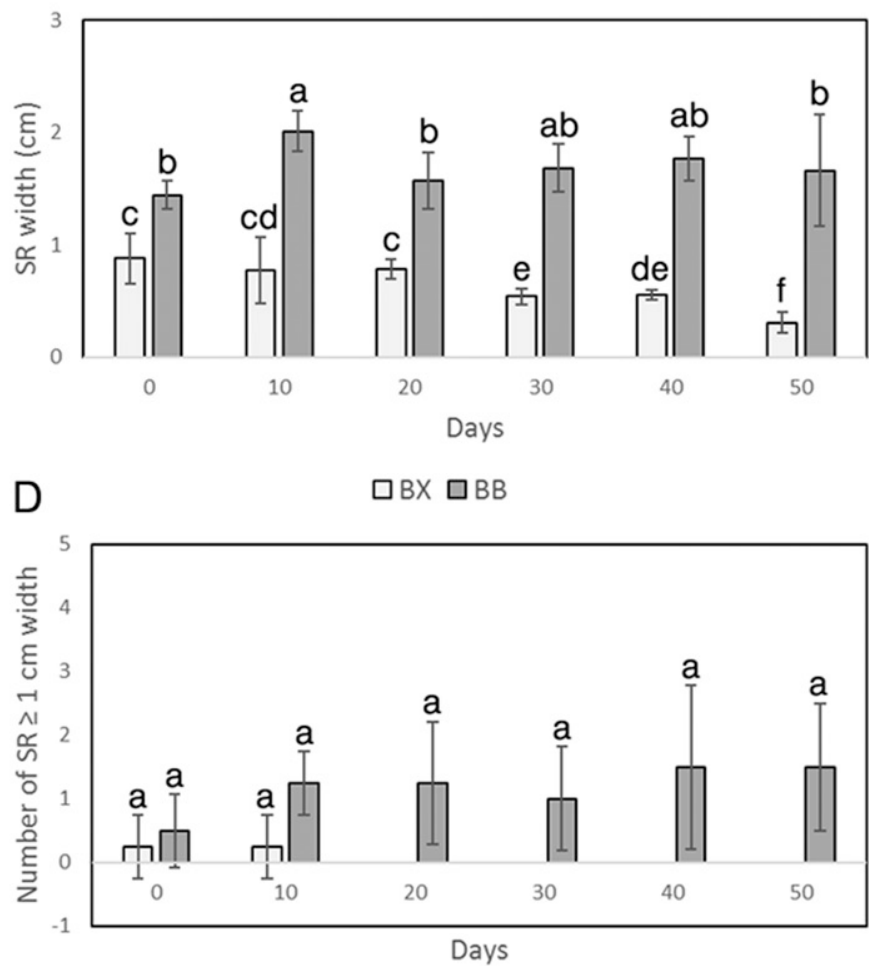

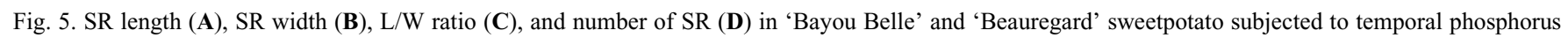
deprivation treatments (Study 2). Mean comparisons were performed on transformed data: log 10 transformed (quantitative data), square root transformed (counts), and arcsine transformed (ratios). Corresponding nontransformed mean values with sD are shown. Columns with different letters differ significantly at the 5\% level by Fisher's least significant difference. BX = 'Beauregard'; BB = 'Bayou Belle'; SR = storage root; $0=$ plants did not receive P for 50 d; $50=$ plants received $\mathrm{P}$ throughout the duration of the study; 10, 20, 30, $40=\mathrm{P}$ was withheld after $10,20,30$, and $40 \mathrm{~d} ; \mathrm{L} / \mathrm{W}$ ratio $=$ length/width ratio. 
the difficulty of observing, quantifying, and interpreting root architecture in general (Lynch, 1995). Currently, there are no published findings, either from greenhouse experiments or field studies, on the specific effect of soil compaction on sweetpotato SRL. In a recent review of available evidence on the role of mechanical impedance on root development in other plant species, Saleem et al. (2018) showed that, in general, soil compaction leads to shorter and thicker roots. Similarly, there is currently no report on the role of $\mathrm{P}$ in determining sweetpotato SRL. Yet, a recent review by Jung et al. (2018) reveals a substantial and growing body of evidence supporting the role of $\mathrm{P}$ in determining root length. These findings lay the foundation for follow-up work focusing on the roles of $\mathrm{P}$ and soil compaction on SRL determination in sweetpotato.

Temporal $-P$. There was a significant planting date $\times$ cultivar interaction for SRL in the temporal -P study; hence, the data for each planting date were presented separately (Figs. 4 and 5). In both planting dates, temporal $-\mathrm{P}$ at $10-\mathrm{d}$ intervals over a $50-\mathrm{d}$ growing period was associated with a trend toward a reduced SRL in both cultivars (Figs. 4 and 5). In the first planting date, the deprivation of $\mathrm{P}$ supply after $10 \mathrm{~d}$ was associated with $25 \%$ reduction in 'Bayou Belle' SRL relative to the control (plants grown in P-sufficient conditions for $50 \mathrm{~d}$ ) (Figs. 4A and 6). After $20 \mathrm{~d},-\mathrm{P}$ treatments did not appear to affect SRLs relative to the control. This was likely in part caused by the limitations of the growing conditions, e.g., the size of the pot. In past studies with this experimental system, root length increase slowed down after $20 \mathrm{~d}$ with the onset of storage root swelling with the accompanying depletion of nutrients in the root zone (Villordon et al., 2012, 2013). Sakamoto and Suzuki (2018) documented the direct influence of pot size on root size but not number in sweetpotato grown in a modified hydroponic system. Because of the possible limitations of the growing conditions, further studies are needed to further the understanding of the possible interactive roles

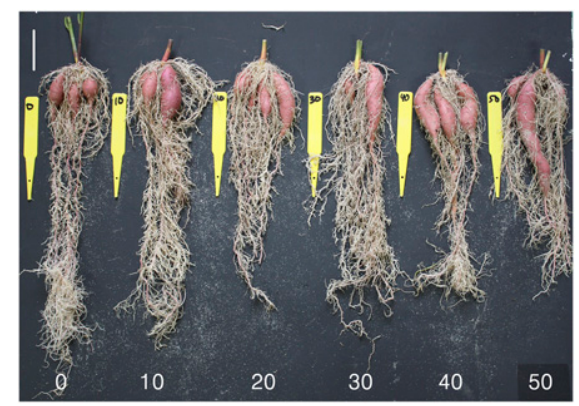

Fig. 6. 'Bayou Belle' storage root samples obtained from plants subjected to temporal phosphorus deprivation and harvested after $50 \mathrm{~d} .0=$ plants did not receive $P$ for $50 \mathrm{~d} ; 50=$ plants received $\mathrm{P}$ throughout the duration of the study; 10, 20, $30,40=\mathrm{P}$ was withheld after $10,20,30$, and $40 \mathrm{~d}$. of genotype and spatial $\mathrm{P}$ availability on sweetpotato SRL in field conditions. Storage root width, $\mathrm{L} / \mathrm{W}$ ratio, and count also varied in two replicate experiments, depending on cultivar. In particular, 'Beauregard' $\mathrm{L} / \mathrm{W}$ ratio appeared to be more sensitive to the temporal -P treatments compared with 'Bayou Belle'. Scant information is available about the temporal effects of -P root length in other plant species. However, Bonnot et al., (2016) have hypothesized that temporal $\mathrm{P}$ deficiency triggers local and long-distance (systemic) molecular, biochemical, and morphological responses in plants to adapt root systems to the heterogeneous distribution and availability of $\mathrm{P}$ in the soil. The current findings have implications in production environments, especially in relation to cultivar-specific responses to supplemental $\mathrm{P}$ fertilizer rates and spatial variation of soil $\mathrm{P}$ availability.

Source plant $P$ status. There was $37 \%$ and $44 \%$ reduction, respectively, in tissue $\mathrm{P}$ concentration after $25 \mathrm{~d}$ in 'Beauregard' and 'Bayou Belle' source plants subjected to $-\mathrm{P}$ treatments (Fig. 7). In general, there was cultivar-specific variation in leaf tissue nutrient concentrations at $25 \mathrm{~d}$ relative to available published critical nutrient concentrations (O'Sullivan et al., 1993) (Table 1). Relative to 'Beauregard' control plants, the nitrogen, potassium, and sulfur leaf nutrient concentrations for 'Bayou Belle' control plants were below published critical nutrient levels (O'Sullivan et al., 1993). These results are consistent with previous data that leaf tissue P content, as well as other nutrients except calcium, declined in-season in fieldgrown sweetpotato plants with accompanying remobilization to the enlarging storage roots (Scott and Bouwkamp, 1974). Using the current experimental methodology, storage root initiation (onset of anomalous cambium development) routinely occurs between 10 and $15 \mathrm{~d}$ in 'Beauregard', and storage roots attain diameters of 0.25 to $0.5 \mathrm{~cm}$ between 20 and $25 \mathrm{~d}$ (Villordon et al., 2009a, 2009b, 2012). The $P$ status of the source plant in turn influenced the response of the daughter plants subjected to $-\mathrm{P}$ treatments, depending on cultivar (Fig. 8). In particular, the $-/-$

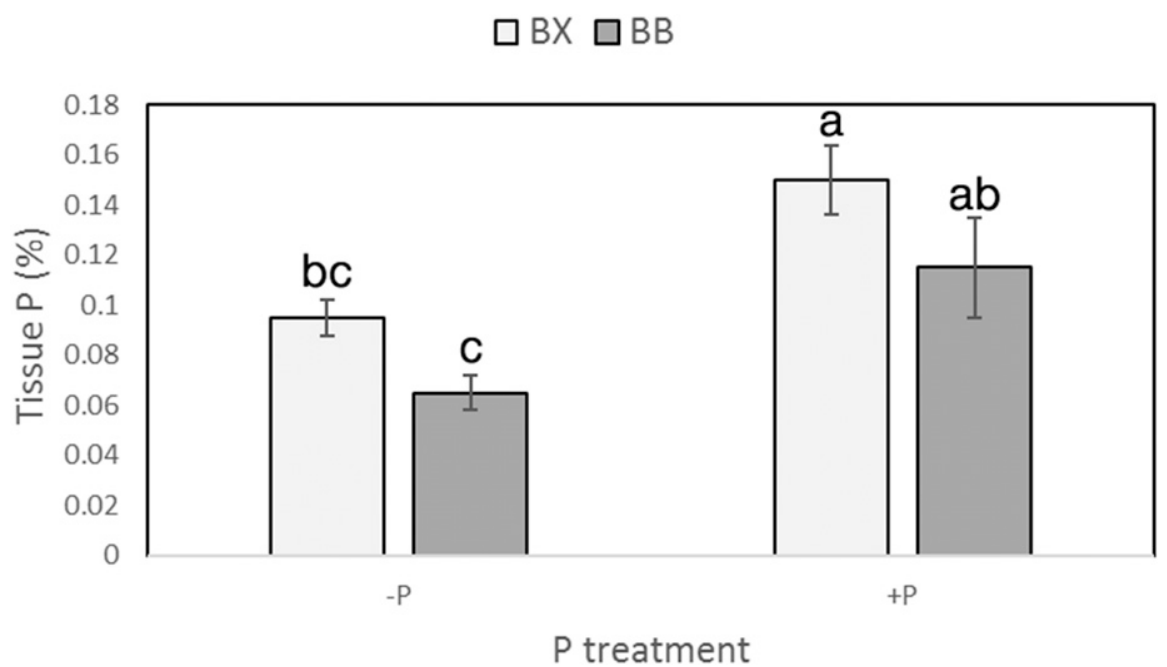

Fig. 7. Leaf tissue $\mathrm{P}$ status at $25 \mathrm{~d}$ after planting in 'Bayou Belle' and 'Beauregard' plants subjected to $\mathrm{P}$ sufficiency and deficiency treatments. Mean comparisons were performed on log 10-transformed data. Corresponding nontransformed mean values with SD are shown. Columns with different letters differ significantly at the $5 \%$ level by Fisher's least significant difference. BX = 'Beauregard'; BB = 'Bayou Belle'.

Table 1. Leaf tissue nutrient concentrations in 'Bayou Belle' and 'Beauregard' sweetpotato as affected by phosphorus deprivation and sufficiency treatments. ${ }^{\mathrm{z}}$

\begin{tabular}{|c|c|c|c|c|}
\hline \multirow[b]{2}{*}{ Nutrient } & \multicolumn{2}{|c|}{ Bayou Belle } & \multicolumn{2}{|c|}{ Beauregard } \\
\hline & $+\mathrm{P}$ & $-\mathrm{P}$ & $+\mathrm{P}$ & $-\mathrm{P}$ \\
\hline Nitrogen, $\%$ & $3.0 \pm 0.57 \mathrm{bc}$ & $2.0 \pm 0.04 \mathrm{c}$ & $4.5 \pm 0.22 \mathrm{a}$ & $3.5 \pm 0.51 \mathrm{ab}$ \\
\hline Potassium, \% & $2.6 \pm 0.42 b c$ & $2.1 \pm 0.13 \mathrm{c}$ & $3.6 \pm 0.01 \mathrm{a}$ & $3.2 \pm 0.34 \mathrm{ab}$ \\
\hline Calcium, \% & $2.1 \pm 0.13 \mathrm{a}$ & $1.8 \pm 0.18 \mathrm{a}$ & $2.2 \pm 0.21 \mathrm{a}$ & $1.8 \pm 0.61 \mathrm{a}$ \\
\hline Magnesium, \% & $0.8 \pm 0.04 \mathrm{a}$ & $0.7 \pm 0.11 \mathrm{a}$ & $0.7 \pm 0.06 \mathrm{a}$ & $0.7 \pm 0.06 \mathrm{a}$ \\
\hline Sulfur, $\%$ & $0.3 \pm 0.02 \mathrm{bc}$ & $0.2 \pm 0.01 \mathrm{c}$ & $0.5 \pm 0.04 \mathrm{a}$ & $0.4 \pm 0.03 \mathrm{~b}$ \\
\hline Iron, ppm & $111.0 \pm 18.39 \mathrm{ab}$ & $89.0 \pm 8.49 b$ & $127.0 \pm 12.73 \mathrm{a}$ & $137.5 \pm 17.70 \mathrm{ab}$ \\
\hline Manganese, ppm & $108.0 \pm 15.56 \mathrm{ab}$ & $88.0 \pm 28.28 b$ & $148.0 \pm 12.73 \mathrm{a}$ & $141.5 \pm 19.09 \mathrm{ab}$ \\
\hline Boron, ppm & $88.5 \pm 6.36 b$ & $68.5 \pm 3.54 \mathrm{c}$ & $136.0 \pm 0.01 \mathrm{a}$ & $102.5 \pm 12.02 b$ \\
\hline Aluminum, ppm & $17.5 \pm 6.36 \mathrm{a}$ & $16.5 \pm 3.54 \mathrm{a}$ & $17.5 \pm 0.71 \mathrm{a}$ & $34.0 \pm 4.24 \mathrm{a}$ \\
\hline Zinc, ppm & $18.5 \pm 2.12 \mathrm{a}$ & $17.5 \pm 0.71 \mathrm{a}$ & $20.0 \pm 2.83 \mathrm{a}$ & $22.5 \pm 3.54 \mathrm{a}$ \\
\hline
\end{tabular}

${ }^{\mathrm{z}}$ Values represent means $( \pm \mathrm{SD})$. Means within rows followed by a common letter are not significantly different based on Fisher's least significant difference mean separation test $(P \leq 0.05)$. Values were $\log _{10}$ transformed. Corresponding nontransformed values are shown. Leaf tissue samples were collected $25 \mathrm{~d}$ after planting. 
treatment (source plant grown without $\mathrm{P}$ / daughter plant grown without $\mathrm{P}$ ) was associated with $48 \%$ reduction in 'Beauregard' SRL relative to the $+/+$ plants. There was also variation in width and $\mathrm{L} / \mathrm{W}$ ratio attributes in 'Beauregard' (Fig. 8B and C). Storage root number was significantly reduced in both cultivars (Fig. 8D). The cumulative results are consistent with the experimental findings of Nassery (1970), who provided evidence that certain plant species will continue to grow using internal $\mathrm{P}$ stores if deprived of external P. These findings also demonstrate how $-\mathrm{P}$ studies in a vegetatively propagated crop species like the sweetpotato can be confounded if the $\mathrm{P}$ status of the source plant and cultivar are not accounted for. In particular, the data support the hypothesis that 'Bayou Belle' is less sensitive to $-\mathrm{P}$ relative to 'Beauregard' after source plant $P$ status is considered. Assuming there is no variability in $\mathrm{P}$ content of cuttings from both cultivars, these results are consistent with findings in other crop species about the existence of genetic variation for $\mathrm{P}$ efficiency (Heuer et al., 2017; Rose et al., 2015; Zhou et al., 2016) and provide the basis for the possible selection for P efficiency in sweetpotato. In our experimental conditions, $-\mathrm{P}$ led to the reduction of boron leaf tissue concentration in 'Bayou Belle' and 'Beauregard' relative to the controls (Table 1). The relationship between low $\mathrm{P}$ availability and reduced boron leaf tissue concentration has been documented previously in radish (Raphanus sativus) (Tanaka, 1967). In addition, $-\mathrm{P}$ reduced sulfur content in 'Bayou Belle' relative to the control. The possible relationship between $\mathrm{P}$ deficiency and leaf tissue sulfur concentration has previously been documented in the model system Medicago truncatula (Tang et al., 2001). Thus, in addition to the reduced $\mathrm{P}$ status of planting materials obtained from P-deficient source plants, these propagules are also potentially deficient in boron and sulfur as well. Further studies are needed to investigate the relationship among cultivar, source plant $\mathrm{P}$ status, and storage root development under field conditions. These experimental data provide a framework for developing approaches and methods for conducting -P studies in sweetpotato. Taken together, these findings are important in the nutrient management of sweetpotato seed systems that rely on extant plants for propagation materials.

In conclusion, our findings corroborate available experimental evidence in model systems and support the hypothesis that the root tip as the site of $\mathrm{P}$ sensing and that $\mathrm{P}$ is involved in root length determination. Advances in the understanding of the molecular mechanisms underlying phosphate sensing in model systems may help to shed light on the role of $P$ sensing in storage root development in sweetpotato. Our data also support emerging evidence that $\mathrm{P}$ appears to be the most important limiting factor to sweetpotato storage root yield determination, i.e., unless $\mathrm{P}$ deficiency is addressed, the deficiency effects of other nutrients remain insignificant (Siose et al., 2017). The observation, quantification, and interpretation of root architecture is difficult and technically challenging. The experimental procedures used previously to validate the timing of storage root formation and measure root architecture variability in 'Beauregard' were sufficient to characterize the effects of $\mathrm{P}$ deficiency on SRL and other storage root attributes. However, these conditions were deemed insufficient for measuring the possible effects of soil compaction on SRL. The results of the current study can lead to follow-up work on the precise role of genotype in sweetpotato root architectural responses to P-sufficient and -deficient conditions. These experimental findings have practical applications in the management of $\mathrm{P}$ in sweetpotato seed and production systems. The results of the current study can lead to follow-up work that investigates cultivar-specific $\mathrm{P}$ requirements and how this information can be used to optimize $\mathrm{P}$ management as it relates to the production of storage roots of consistent length and shape. The methods and approaches used in the current study can be adopted and modified in follow-up investigations that seek to shed light on the precise mechanisms of SRL determination in sweetpotato.
A

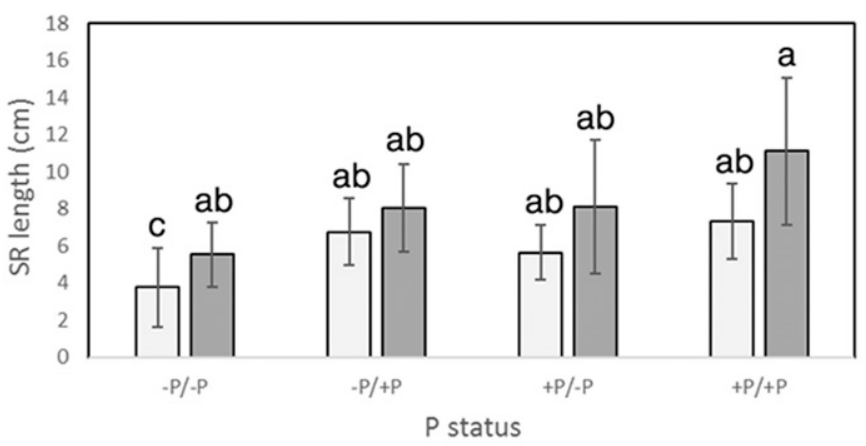

C

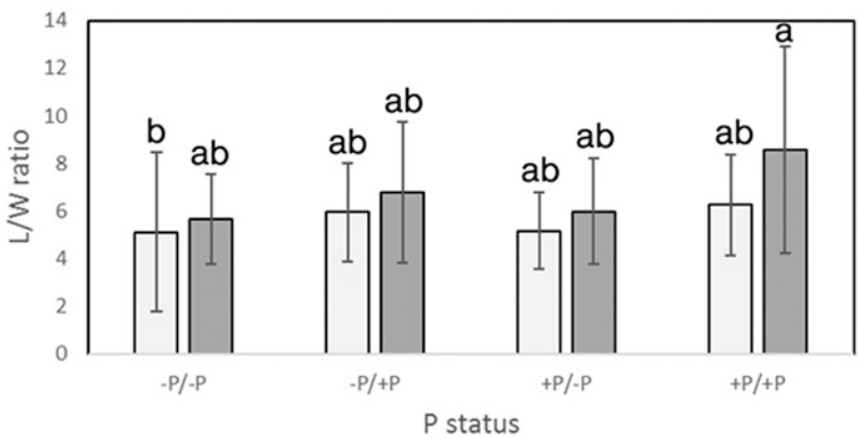

B

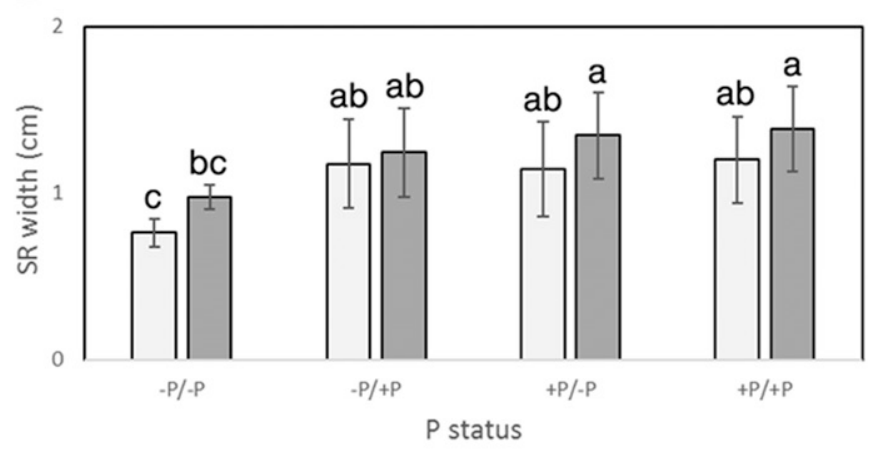

D

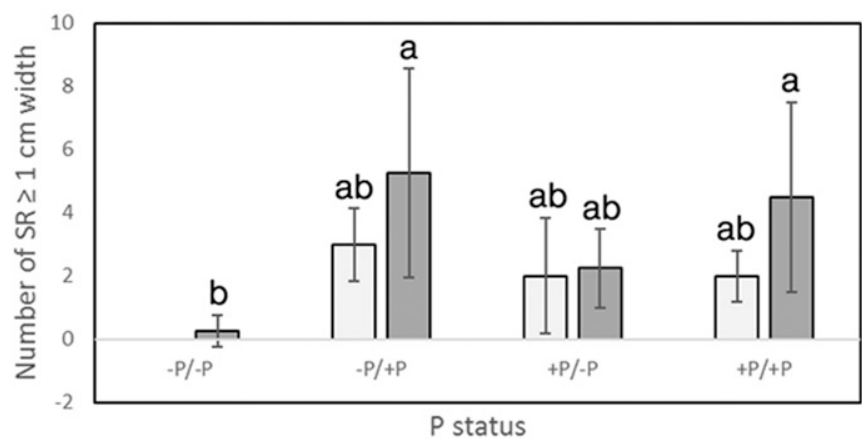

Fig. 8. SR length (A), SR width (B), L/W ratio (C), and number of SR (D) in 'Bayou Belle' and 'Beauregard' sweetpotato derived from source plants subjected to P sufficiency and deprivation and subsequently grown in $\mathrm{P}$ sufficiency and deprivation treatments. SR=storage root, $\mathrm{L} / \mathrm{W}$ ratio=length/width ratio. Mean comparisons were performed on transformed data: $\log 10$ transformed (quantitative data), square root transformed (counts), and arcsine transformed (ratios). Corresponding nontransformed mean values with standard deviations are shown. Columns with different letters differ significantly at the 5\% level by Fisher's least significant difference. $\mathrm{BX}=$ 'Beauregard'; $\mathrm{BB}=$ 'Bayou Belle'; $-\mathrm{P}=$ no phosphorus; $+\mathrm{P}=$ with phosphorus; $\mathrm{L} / \mathrm{W}$ ratio $=$ length $/$ width ratio. 


\section{Literature Cited}

Abel, S. 2017. Phosphate scouting by root tips. Curr. Opin. Plant Biol. 39:168-177.

Bengough, A.G. and C.E. Mullins. 1990. Mechanical impedance to root growth: A review of experimental techniques and root growth responses. Eur. J. Soil Sci. 41:341-358.

Bilderback, T.E. and W.C. Fonteno. 1987. Effects of container geometry and media physical properties on air and water volumes in containers. J. Environ. Hort. 5:180-182.

Bonnot, C., B. Pinson, M. Clément, S. Bernillon, S. Chiarenza, S. Kanno, N. Kobayashi, E. Delannoy, T.M. Nakanishi, L. Nussaume, and T. Desnos. 2016. A chemical genetic strategy identify the PHOSTIN, a synthetic molecule that triggers phosphate starvation responses in Arabidopsis thaliana. New Phytol. 209:161-176.

Bouwkamp, J.C. 1985. Production requirements, p. 9-33. In: J. Bouwkamp (ed.). Sweetpotato products: A natural resource for the tropics. CRC Press, Boca Raton, FL.

Costa, C., F. Antonucci, F. Pallottino, J. Aguzzi, D.W. Sun, and P. Menesatti. 2011. Shape analysis of agricultural products: A review of recent research advances and potential application to computer vision. Food Bioprocess Technol. 4:673-692.

Heuer, S., R. Gaxiola, R. Schilling, L. Herrera-Estrella, D. López-Arredondo, M. Wissuwa, E. Delhaize, and H. Rouached. 2017. Improving phosphorus use efficiency: A complex trait with emerging opportunities. Plant J. 90:868-885.

Hoagland, D.R. and D.I. Arnon. 1950. The waterculture method for growing plants without soil. Circular. California agricultural experiment station, 347 (2nd ed.).

Hoque, M.A. and K.K. Saha. 2017. Design and development of a manual potato cum sweet potato slicer. J. Sci. Technol Environ. Informatics 5:395-401.

Jung, J.Y., M.K. Ried, M. Hothorn, and Y. Poirier. 2018. Control of plant phosphate homeostasis by inositol pyrophosphates and the SPX domain. Curr. Opin. Biotechnol. 49:156-162.

Kaiser, J.P., A. Reinmann, and A. Bruinink. 2006. The effect of topographic characteristics on cell migration velocity. Biomaterials 27:5230-5241.

Kellermeier, F., P. Armengaud, T.J. Seditas, J. Danku, D.E. Salt, and A. Amtmann. 2014. Analysis of the root system architecture of Arabidopsis provides a quantitative readout of crosstalk between nutritional signals. Plant Cell 26:1480-1496.

LaBonte, D., A. Villordon, T. Smith, and C. Clark. 2013. Sweetpotato plant named '07-146'. USA Patent USPP23785. July 30.

Lipiec, J., R. Horn, J. Pietrusiewicz, and A. Siczek. 2012. Effects of soil compaction on root elongation and anatomy of different cereal plant species. Soil Tillage Res. 121:74-81.

Loboski, C.A.M., R.H. Dowdy, R.R. Allmaras, and J.A. Lamb. 1998. Soil strength and water content influences on corn root distribution in a sandy soil. Plant Soil 203:239-247.
Lowe, S.B. and A. Wilson. 1974. Comparative analysis of tuber development in six sweet potato (Ipomoea batatas (L.) Lam) cultivars. Ann. Bot. 38:307-317.

Lynch, J. 1995. Root architecture and plant productivity. Plant Physiol. 109:7-13.

Materechera, S.A., A.R. Dexter, and A.M. Alston. 1991. Penetration of very strong soils by seedling roots of different plant species. Plant Soil 135:31-41.

Medici, A., A. Marshall-Colon, E. Ronzier, W. Szponarski, R. Wang, A. Gojon, N.M. Crawford, S. Ruffel, G.M. Coruzzi, and G. Krouk. 2015. AtNIGT1/HRS1 integrates nitrate and phosphate signals at the Arabidopsis root tip. Nat. Commun. 6:6274.

Mortley, D.G. and W.A. Hill. 1990. Sweetpotato growth and nitrogen content following nitrogen application and inoculation with Azospirillum. HortScience 27:758-759.

Nassery, H. 1970. Phosphate absorption by plants from habitats of different phosphate status. New Phytol. 69:197-203.

Noda, T., Y. Takahata, T. Sato, H. Ikoma, and H. Mochida. 1996. Physicochemical properties of starches from purple and orange fleshed sweet potato roots at two levels of fertilizer. Starke 48:395-399.

O'Sullivan, J.N., C.J. Asher, F.P.C. Blamey, and D.G. Edwards. 1993. Mineral nutrient disorders of root crops of the Pacific: Preliminary observations on sweet potato (Ipomoea batatas). Plant Soil 155:263-267.

Oussible, M.R.K.C., R.K. Crookston, and W.E. Larson. 1992. Subsurface compaction reduces the root and shoot growth and grain yield of wheat. Agron. J. 84:34-38.

Rolston, L.H., C.A. Clark, J.M. Cannon, W.M Randle, E.G. Riley, P.W. Wilson, and M.L. Robbins. 1987. 'Beauregard' sweet potato. HortScience 26:1338-1339.

Rose, T.J., A. Mori, C.C. Julia, and M. Wissuwa 2015. Screening for internal phosphorus utilisation efficiency: Comparison of genotypes at equal shoot $\mathrm{P}$ content is critical. Plant Soil 401:79-91.

Sakamoto, M. and T. Suzuki. 2018. Effect of pot volume on the growth of sweetpotato cultivated in the new hydroponic system. Sustain. Agr. Res. 7:137-145.

Saleem, M., A.D. Law, M.R. Sahib, Z.H. Pervaiz, and Q. Zhang. 2018. Impact of root system architecture on rhizosphere and root microbiome. Rhizosphere 6:47-51.

Schneider, C.A., W.S. Rasband, and K.W. Eliceiri. 2012. NIH Image to ImageJ: 25 years of image analysis. Nat. Methods 9:671-675.

Scott, L.E. and J.C. Bouwkamp. 1974. Seasonal mineral accumulation by the sweetpotato. HortScience 9:233-235.

Siose, T.S., A.K. Mohammed, and A.B. Tulin 2017. Determination of limiting nutrient to sweetpotato (Ipomoea batatas L.) growth on Samoa oxisol using a nutrient omission technique. Ann. Trop. Res. 39:105-199.
Solis, J., A. Villordon, N. Baisakh, D. La, D. Bonte, and N. Firon. 2014. Effect of drought on storage root development and gene expression profile of sweetpotato under greenhouse and field conditions. J. Amer. Soc. Hort. Sci. 139:317-324.

Svistoonoff, S., A. Creff, M. Reymond, C. SigoillotClaude, L. Ricaud, A. Blanchet, L. Nussaume, and T. Desnos. 2007. Root tip contact with lowphosphate media reprograms plant root architecture. Nat. Genet. 39:792-796.

Tanaka, H. 1967. Boron absorption by crop plants as affected by other nutrients of the medium. Soil Sci. Plant Nutr. 13:41-44.

Tang, C., P. Hinsinger, J.J. Drevon, and B. Jaillard. 2001. Phosphorus deficiency impairs early nodule functioning and enhances proton release in roots of Medicago truncatula L. Ann. Bot. 88:131-138

Tang, W., Y. Zhang, Q. Li, M. Kou, X. Wang, H. Yan, D. Ma, and Y. Liu. 2017. Screening and breeding of sweetpotato varieties suitable for mechanical harvesting. Agr. Sci. Technol. 18:971-974.

Taylor, H. and G.S. Brar. 1991. Effect of soil compaction on root development. Soil Tillage Res. 19:111-119.

Villordon, A. and H. Carroll. 2002. Digital image analysis of sweetpotato storage roots in herbicide trials. HortScience 4:669-670.

Villordon, A., D. LaBonte, and N. Firon. 2009a. Development of a simple thermal time method for describing the onset of morpho-anatomical features related to sweetpotato storage root formation. Scientia Hort. 121:374-377.

Villordon, A., D.R. LaBonte, N. Firon, Y. Kfir, E. Pressman, and A. Schwartz.2009b. Characterization of adventitious root development in sweetpotato. HortScience 44:651-655.

Villordon, A., D. LaBonte, J. Solis, and N. Firon. 2012. Characterization of lateral root development at the onset of storage root initiation in 'Beauregard' sweetpotato adventitious roots. HortScience 47:961-968.

Villordon, A., D. Labonte, N. Firon, and E. Carey. 2013. Variation in nitrogen rate and local availability alter root architecture attributes at the onset of storage root initiation in 'Beauregard' sweetpotato. HortScience 48:808-815.

Villordon, A.Q. and C.A. Clark. 2014. Variation in virus symptom development and root architecture attributes at the onset of storage root initiation in 'Beauregard' sweetpotato plants grown with or without nitrogen. PLoS One 9:e107384

Wolfe, D.W., D.T. Topoleski, N.A. Gundersheim, and B.A. Ingall. 1995. Growth and yield sensitivity of four vegetable crops to soil compaction. J. Amer. Soc. Hort. Sci. 120:956-963.

Zhou, T., Y. Du, S. Ahmed, T. Liu, M. Ren, W. Liu, and W. Yang. 2016. Genotypic differences in phosphorus efficiency and the performance of physiological characteristics in response to low phosphorus stress of soybean in Southwest of China. Front. Plant Sci. 7:1776. 